\title{
A Self-Finding through Destruction: Through the Analysis of Sula's Behavior, in the Text of "Sula"
}

\author{
Mia Kim \\ Associate Professor of Jeonju University \\ Kmia14@nate.com
}

\begin{abstract}
This paper speaks of the displacement and fragmentation of black identity. This also shows ${ }^{1}$ human being's inner estrangement and the failure to establish meaningful relationship with the community in modern society through the main hero of this novel, Sula in "Sula through the cruel processes of life like self-destructive narcissism, no-ego etc in her long life journey. Sula had to be isolated and persecuted from the other women in the community they had grown up together. They never allow her any freedom threatening the stereotyped social norm they preserved, even though everybody knew that the norm was wrong. They constantly require each other to live as the sacrifice of the social custom.

The people in social community constantly pursue alter-ego from the overwhelming reality. They make Sula a scapegoat of the fixed social norm. There is no future and no vision for the future. However, in the long run, Sula dies after sowing the seed of positivity for future as a complete existence with the subjectivity. There is a movement of women for change after her death. The sacrifice of Sula who was a real woman with solid subjectivity makes a huge change for this black community. This paper will prove that a woman's reckless challenge who had a strong ego and subjectivity helps the people belonging to the closed and patriarchal society to open a new chapter of their life.

In the practical sense of fusion of psychology, art, politics and culture, this research will enlighten the basic issue of women's self-finding living their life in modern society and it would be a meaningful process for modern women to live their life more positively and actively with the complete self-subjectivity.
\end{abstract}

Keywords: Self-Destruction, Fragmented Subject, Self-Finding, Community, Co-Existence.

\section{Introduction: Modern Black Literature beyond the Confines of Postmodernism}

Modern society which is beyond the peak of post modernism is revealing the nature of disintegration throughout society. In the dark mood of modern era, where the role of leader or center in the family, society or culture, it must be meaningful to look into more specifically the role of leader or center in the family, society or culture where they belonged to. In the process of the research, this paper aims to examine the sense of the subject of society and culture through the analysis of Sula in Toni Morrison’s 『Sula』(1973). For the concrete research, this paper will analyze the text, ${ }^{\nabla}$ SulaJ』 on the basis of the feminist criticism which shows the author's view on the well-established female identity and the world[1].

\footnotetext{
${ }^{1}$ Article history:

Received (May 13, 2019), Review Result (June 9, 2019), Accepted (July 4, 2019)
} 
The literature that feminist criticism pursues has the prerequisite to truly re-express the experience of women and to comprehensively show the various width and breadth of women's experience. Under the name of this cause, this novel tries sowing the seeds in the land of a rough reality through Sula who lived a life of destruction and division, and made a change of women. Sula's life is full of different experiences achieving the fruits of abundant growth through the period of chaos. This study will focus on an active force of subjective woman which is the driving force of enormous power that prevents domestic, social, and cultural division and disintegration, regardless of the time[2].

This research will examine the growing process of Sula in relation to her various experiences of life who was constantly suffering from a sense of selflessness and loss in a society and couldn't survive without denying herself. In addition, this study also looks at how individual female growth can unite the cultural ideologies of disintegration and division into harmony and unity.

\section{Black Women's Incomplete Identity}

Lots of African American writers tried hard to search for the root of their culture and customs to get back their self-esteem. It was a long journey for them to face the reality and trace back their ancestors' pain, devastation and ordeal immersed into their sweat on a daily basis of their life. In order for the exploration of the work, African Americans needed a courage and wisdom to beat any possible blame and attack to them[3]. Discrimination and absurdity was a common thing happening to them everyday life. No generosity or complete freedom, no reverence to the human being of Blacks was there.

Especially for African American women, there is a rare chance to look into their inner self. There was not any respect to women even from the African American men. African American women who suffered from house chores, taking care of white children as a nanny and sexual abuse by the white men. They could not have any resting place in life, even at home. Moreover, they struggled with the sense of guilty because they could not do their duty as a mother. Some people denounce the lack of African American women's motherhood to their children. Quite a few African American female writers including Toni Morrison, Zora Neal Hurston, Alice Walker and so on tried hard to embrace these African American women's painful life and barren ego into their novels[4].

Toni Morrison's Sula explores, among other things, how a black woman full of self-creative energies is received in a typically black community. But most criticism about this novel has been made largely in terms of general feminist perspective. Of course, this novel deals with such general feminist themes as marriage, family, female sexuality, female friendship and mother-daughter relation. But in order to get to the core vision of Morrison' unique art created in this novel, understanding fully the black community called "the Bottom" is essential. The landscape of the Bottom can be read as a kind of nightmarish wasteland pervaded by both racism and sexism which is rendered in this novel as a by-product of the greater human crime, racism. Racism in this novel is by no means overt. Rather, in Morrison's subtle art, it is, as Barbara Christian also observes, something "so pervasive" that has become "so illusive" [5].

In the novel, no remarkable white individual appears and there are provided only glimpse of what whites are doing, only as an indirect social background for the black community. And no character in the novel seems to call seriously into question whether their predicament and sexist culture might have any bearing on the racist white society. Nor has Toni Morrison in her essay or interviews ever directly induced the reader to interpret this novel in terms of either antiracist or antisexist line. In addition, this novel is probably the least overtly antiracist work in the whole 
of Morrison's novels. Nevertheless, as Diane Gillespie also pointed out, understanding the novel without the background of the white dominated society seems almost impossible.

Although Sula is a novel centered around black people and black culture, the power of the white logos is still very much in

evidence. Blackness is still being used here to mean absence or negation: "Black center" is read here as "no center" [6].

Accordingly, the purpose of this paper is to discuss in detail the black community the Bottom as an indirect victim of both racism and is by-product, sexism and the relation between the community and the heroine, in other words, how Sula functions as both an oppressed model and an active agency-model in the society.

The setting, the Bottom, which is a typical black community, takes an important place in the novel. As many critics also observed, community is no doubt a central concern in most writings by black women writers. Morrison herself often stresses the special meaning and recollection that traditional black communities bring to her psyche and art. In representing black community Morrison looks quite objective and dispassionately neutral most of the time. In other words, in it there is both "native" pain and joy that only blacks have survived and enjoyed. But here in this novel, Morrison's landscape of the Bottom is uniquely bleak and dreary, especially in terms of the heroine Sula's tragedy. Although the female friendship between Sula and Nell is presented as a kind of emotional relief, as the only true love-relation. The significance the setting takes in this novel is also proved by analyzing the narrative structure Morrison employs, the structure reminding of something like a Chines box.

In next chapter, this paper will more specifically approach to the content of the novel to examine Sula's behavioral pattern causing her to be scarred and isolated from the community. This study will more focus on analyzing her self-destructive attitude to find her identity[7].

\section{A Subjective Self-Finding through Disintegration: the Study on the Behavioral Patterns of Sula in "Sula"}

The society Sula belonged to is the community dominated by patriarchal characteristics restricting and suppressing women's life. They regard women as the object of restriction, suppression and treat wife as the owned and controlled, and the weak and subordinate ones[8]. The meaning of marriage for men in the society where Sula belonged to can be guessed through the notion of marriage of Sula's close friend, Nell and her husband, Jude. For him, marriage is the only systematical device of society playing a role of a pacifier in bursting out his instinctive desire and in expressing himself out in the society where they deprive him of any opportunity for the future.

The more he thought about marriage, the more attractive it became. Whatever his fortune, whatever the cut of

his garment, there would always be the hem--the truck and fold that hid his raveling edges; a someone sweet,

industrious and loyal to shore him up. ... Without that someone he was a waiter hanging around a kitchen

like a woman. With her he was head of a household pinned to an unsatisfactory job out of necessity. The two

of them together would make one Jude[9].

Jude's decision to get married is originated from his frustration as a man from the discriminative society. For him, the role of wife is a kind, diligent and loyal being who stays in a subordinate position in a family and let her husband prove his manliness and protects and 
comforts him from the pressures of the outside world. In other words, a black woman who is the one who restores the pride of a wounded man by being alienated from the social power structure. Therefore, the black-family marriage system represented by Jude and Nell is more complicating than that of white-family marriage system. Black men's desire to possess and control must be met in the family through their wives, so as a result, black women become hook men and serve as breakwater to withstand racial discrimination outside the home. Sula believes that this existing marriage system is a closed one that does not give a black woman a place for self-esteem and imagination to exist, assuming an ownership relationship that makes a woman's life entirely dependent on the other man. Sula's cynical criticism of marriage, which equates marriage to the tomb of women's self and imagination, is aimed at the reality of patriarchal marriage, which is filled with "hurt dreams and bitter remorse", and black women whose "sweet taste" is drained out of caring for their husbands and self-employed jobs[10]. For Sula, the conventional way of life for women in the village, including Nell, is a life that is not beyond the confines of men and children. From Sula's point of view, the way Nel and Bottom village women live in cobweb-like relationships, giving up their egos, is not a real life, but a survival that is just a state of paralysis that is slowly dying like a tree stump.

Sula in the vibe of having the meaning of the relationship with men tries hard to sow the seeds of the ideology of hope in a barren and depressing land. Sula, who belonged to an era in which women's lives only mean things in relationships with men, wants to sow the seeds of her ideology of hope in this barren and gloomy land. She rejects such a framework of social oppression and insists that her life is hers and only wants to explore her feelings. Sula's selfportrait, which aims to define herself beyond the limits of gender, class and race, hurts the pride and vanity of women who belong to the same society in reverse. Women in Sula's community are more serious than they have in the past, trying to counteract Sula's fundamental criticism of their lives and justify the norms they have adhered to by defending the norms of their community. This male-centered value system makes Sula the scapegoat of free egos, so that she can't find any agreement from the repressive community and alienated and split from the community, This overall process causes Sula destroy herself more and more and makes her lock herself in a somber ego[11].

Sula's rejection for the typical and patriarchal marriage is accepted as a challenge and rebellion against the type of woman her society defines, and she is submerged into 'selfdestructive narcissism by being isolated and cut off[12]. Morrison describes this situation of Sula, that is to say, who finds no tools to self-realize as "an artist without an art form"[13]. In the face of the oppressive reality of this social system, Sula is isolated and alienated, leaving him in danger, without finding any tools to realize herself, and eventually dies without creative sublimation of self-seeking. Susa Willis regards Sula as a victim of a patriarchal society centered on men and a future woman ahead of her time.

This study was conducted with the same viewpoint of Susan Willis, who identified Sula's departure from these communities, her immersion into herself, her indifference to the world and her insatiable appetite for the world as a state of self-lessness[14]. In other words, Sula has no desire to attract men's attention, no greed for property or things, no tough self. Nothing in which the concept of restraint, oppression, possession, and domination was embedded in Sula, who rejected this stereotypical system of values, was of value, and she could only be drawn into herself more. Eventually, Sula's lack of self would have to be seen as having no center for her ego to lean on. 


\section{Conclusion: Presentation of the Future Black Women's Perspective}

Self-pursuing patterns as examined above appear to be violent and impulsive resistance to domination, indifference to patriarchal values, rejection of patriarchal marriage, and immersion in sex as a means of self-discovery. As Barbara Smith indicates, Sula's incomprehensible attitudes can be interpreted positively as follows, given that they stem from rejecting the maledominated system. Her challenge should be interpreted as a firm attitude rejecting malecentered ideology, her impulsiveness as a desire to be faithful to her feelings and thoughts, her belief that her ferocity cannot yield to dominance at all costs, and her selfishness should be interpreted as thorough self-love[15].

Sula ends up being crushed and frustrated by her community, but this life of Sula can be interpreted as a life that is physically dying but glorious, as Barbara Smith said. While selfseeking is achieved by challenging social oppression and intolerance through the destruction of division and deviation, Sula's choice of death but by the flesh alone is clearly presenting a more active and self-reliant future black female image to black women.

Likewise, this paper aimed to look into Toni Morrison's attempt to break down the boundaries between oppositional values under the name of the typical social norm through her second novel, Sula. Morrison suggests important implications in terms of race and gender in the background of male centered society. Sula representing Morrison's soul pursues a new vision free from issues of race and gender, male and female, good and evil, individual and community, presence and absence by subverting traditional, racial or gender-biased ideas thoroughly.

Morrison digs into the process of her argument by demolishing the boundaries through the measure I will debate as follows. First, it is the spiral narrative structure. This means the text of Sula is not proceeded in chronological order. Second, the past and the present of this text hovers over freely. That is how the new layers of meaning accumulate as supplementary explanations are given over time. Third, it is the deconstruction of the boundaries where the familiar binary oppositions are slated and a new vision of integration from that deconstruction are being born.

In the long run, the seed of integration from the total demolition is sprouted after the death of Sula. Nell finally realizes the significance of her love through losing her friend, Sula. This Nell's devastating experience lets her surpass her love for her husband, Jude. Furthermore, it lets Nell and the women in the community, Bottom, transcend the boundary of the limit of reality. They are eventually breaking down the boundary and accepts a new vision for the future.

\section{Vision for the Future}

As examined above, it is another difficult process for someone to accept their own self as who they are and stand as the subject of love and harmony. However, those who are forced to sow their own self through the process of hardship and adversity, such as deviance, division, conflict and harmony, will express the power of positivity[16].

This study took a look at the pilgrimage process of Sula's life, which set the cornerstone of the importance of positive and harmonious values through the hard process of self-destruction and division. Such a culture where the ideology of affirmation and harmony can be imbued is born in the circumstance where a woman can make a through self-discovery with her subjective ego. A stronger culture of harmony and positivity can be formed when a woman recognizes her own self-reliance and starts from it. In a community where individual female self-restoration is intact, the values of harmony rather than family dissolution, unity rather than social division, and coexistence rather than lack of culture will be spontaneously overflowed. 


\section{References}

[1] Butler-Evans, Elliot. Race, Gender and Desire: Narrative Strategies in the Fiction of Toni Morrison, and Alice Walker. Philadelphia: Temple UP(1989).

[2] Chirstian, Barbara. "Trajectories of Self-Definition: Placing Contemporary Afro-American Women's Fiction." Conjuring: Black Women, Fiction, and Literary Tradition. Ed. Marjorie Pryse and Hortense J. Spillers. Bloomington: Indiano UP, 1985. 233-249., Kandice. Journal of Asian American Studies (2003), Vol.6, pp. 931.

[3] Cornel, West. Race Matter. New York: Random House(2001).

[4] Davis, Christina. "An Interview with Toni Morrison." A Conversation with Toni Morrison. ed. Daniel TaylorGuthrie. Jackson: UP of Mississippi(1994)

[5] George, Sheldon. "Approaching the 'Thing' of Slavery: A Lacanian Analysis of Toni Morrison's Writing." African American Review(2012), Vol.45, pp. 112-30.

[6] Gillespie, Diane, and Missy Dehn Kubitscheck. Toni Morrison's Fiction: Contemporary Criticism. David L. Middleton. New York: Garland(1997)ed. pp. 62-91.

[7] Goelitz, A. From Trauma to Healing. New York: Routledge(2013).

[8] Rigney, Barbara Hill. The Voices of Toni Morrison. Columbus: Ohio State UP(1991).

[9] Morrison, Toni. Sula. New York: Knopf(1992).

[10] Chirstian, Barbara. "Trajectories of Self-Definition: Placing Contemporary Afro-American Women's Fiction." Conjuring: Black Women, Fiction, and Literary Tradition. Ed. Marjorie Pryse and Hortense J. Spillers. Bloomington: Indiano UP, (1985). 233-249.

[11] Butler-Evans, Elliot. Race, Gender and Desire: Narrative Strategies in the Fiction of Toni Morrison, and Alice Walker. Philadelphia: Temple UP(1989).

[12] Morrison, Toni. Lecture and Speech of Acceptance, upon the Award of the Noble Prize for Literature, Delivered in Stockholm on the Seventh of December, Nineteen Hundred and Ninety-three. New York: Knopf(1997).

[13] Watkins, Susan. Twentieth-Century Women Novelists: Feminist Theory into Practice. Houndmill: Palgraye(2001).

[14] Smith, Barbara. "Toward a Black Feminist Criticism." All the Women Are White, All the Blacks are Men, But Some of Us Are Brave. Eds. Gloria T. Hull, Patricia Bell Scott, and Barbara Smith. New York: Feminist(1988), pp. 156-175.

[15] Smith, Valerie. "Black Feminist Theory and the Representation of the "Other". Changing Our Own Words. Ed. Cheryl A. Wall. New Brunswick: Rutgers UP(2009), pp. 38-57.

\section{Authors}

\section{Mia Kim}

Associate Professor of Jeonju University, Majored in African American Literature Studied and published the papers in relation to African American music, blues and black identity through the analysis of the works of Ralph Ellison, Alice Walker and Toni Morrison. 